\title{
The Effects of Organizational Performance on the Relationship between Perceived Organizational Support and Career Satisfaction: An Application on Insurance Industry
}

\author{
Erdem Kirkbesoglu \\ Faculty of Commercial Sciences, Baskent University \\ Eskisehir Yolu, 20.km Baglica Kampusu, Ankara, 06810, Turkey \\ Tel: 90-312-246-6666/1724Ｅ-mail: erdemk@baskent.edu.tr \\ Emir Huseyin Ozder \\ Faculty of Commercial Sciences, Baskent University \\ Eskisehir Yolu, 20.km Baglica Kampusu, Ankara, 06810, Turkey \\ Tel: 90-312-246-6666/1721Ｅ-mail: ehozder@baskent.edu.tr
}

Received: Feb. 13, $2015 \quad$ Accepted: Feb. 26, $2015 \quad$ Published: April 1, 2015

doi:10.5296/jmr.v7i3.7094 URL: http://dx.doi.org/10.5296/jmr.v7i3.7094

\begin{abstract}
This study aims to examine the effects of organizational performance on the relationship between perceived organizational support (POS) and career satisfaction (CSAT) of employees. Our research question facilitates to understand how the interaction between POS and CSAT changes in the process of adaptation to environmental pressures. In order to find answers to our research question we carried out quantitative research and applied questionnaire as our method of data collection. Research sample is constituted with 10 insurance companies and 194 employees working in these companies. At the end of the study, our findings support that perceived organizational support effects career satisfaction more in high performance organizations, compared to low performance organizations.
\end{abstract}

Keywords: Organizational Performance, Perceived Organizational Support, Career Satisfaction, Insurance 


\section{Introduction}

Conditions of competition ongoing in organizational life put forward a necessity of harmony between the microstructure of organizations and their behaviors to the environment. In order for the organizations to adapt to their environments and to be able to compete, organizational design is expected to have the quality to serve organizational purpose and goals. Organizational efficiency and legitimacy correlate not only with interorganizational actions but also with the stable and trust environment that will be assured in the organization. For this reason, organizations need regularity first in their own microstructures in the name of adapting to environmental changes or to survive in the long term.

Fulfillment of "employees", who are addressed within the context of the organization's immediate environment, and their expectations can be accepted as the main element in assuring intraorganizational regularity. This group, which has a great variety of expectations, has the capability to use critical resources in the organization on behalf of the organization and in the most efficient way. As the knowledge and experience an employee has increases, dependency to that person within the organization is also expected to increase. An important parallelism exists between the expectation of an employee from the organization and that person's concerns for the future. Increasing concerns for the future will bring out many behavioral changes as well.

One of the most basic factors of the mutual interaction between organizational structure and employee behavior and attitudes is without a question the career opportunities in the organization. For as much as organizational structure will determine the executive positions in the organization. Switching between positions, difficulty of promotion criteria, waiting periods and reward differences between positions are results of organizational structure as well as indicators of career opportunities. On the other hand, constraint in career opportunities is obvious to increase employee turnover. In consequence, career satisfaction level of employees is an important factor in maintaining the harmony within the organization.

Determining the priorities that increase career satisfaction of employees and measures to be taken at the executive level according to these priorities are important. Although actors at the top management of the organizations have the tendency to reduce the concerns of employees for the future; sometimes this is not perceived or interpreted correctly by the employees. Opportunity and privileges provided by the organization to its employee can be interpreted differently according to the upper management and employees. In case this difference appears, a set of negative perceptions will be probable to be formed in employees regarding career satisfaction.

Our purpose in this study is not only to examine the relationship between organizational support level that employees perceive and their career satisfaction, but also to test how the interaction between these variables changes in the process of adaptation to environmental pressures. Therefore, our aim is to examine whether this relationship power differs according to the performances of organizations.

\section{Perceived Organizational Support}

Individuals perceive, assess and personally interpret the physical and social changes, while they maintain their daily lives. The individual is influenced by the environment, shape her/his 
behaviors by the measure of her/his perceptions, and exhibit new behaviors. Therefore, the statement of "perception" is a concept about "the individual perceiving her/his environment". How the actors in the organizations taking place in executive positions or some practices in the organization are perceived by employees will differ from person to person. According to Eisenberger et al (1986), overall attitudes of the employees will change according to the effort the organization gives for the employees and the value it gives to their happiness. This perception, which determines the attitude and behaviors of the employees to their organizations, is a reflection of the social change between employees and the organization. Likewise, the relationship between employees and the organization is the relationship of a kind of mutual change, an interchange (Blau, 1964).

According to social change theory, the utility that one person gets from another will lead to the behavior of repaying this utility within the process (Gouldner, 1960). Through previous practices, employees subconsciously question to what extent the organization acts out of concern for them (Rhoades et al., 2001). If the mutual relationship indicates a change that has certain rules and benefits both parties; the relationship of the employees with their organizations base on the ground of mutual trust, loyalty and mutual commitment in time (Cropanzano and Mitchell, 2005). Existence of such a relationship indicates that employees have positive thoughts about the organization and their outputs will be for the benefit of the organization (Saks, 2006). Perceived organizational support is defined as the perceptions for the organization to give importance to the contribution of the employees and to care about their wellbeing, and feelings regarding activities affecting the employees to be performed voluntarily (Eisenberger, et al., 1986). Therefore, employees shape their efforts and performances about their jobs depending on the material and spiritual rewards they expect the organization to provide in the future.

Meta analyses of Rhoades and Eisenberger (2002) put forward that perceived organizational support is influenced by three basic antecedents. These are rewards and work conditions, support taken from the superior and procedural justice. Rewards and working conditions, which are the first antecedents, affect organizational support perception in a positive way in terms of providing effects that improve the skills of the employees within the organization (Wayne et al., 1997), creating a feeling of being noticed by the upper management (Eisenberger et al., 1999) and adding autonomy to the employees (Eisenberger et al., 1999). Perceived superior support, which is another antecedent, means the perception of the employee about to what extent her/his contribution in the organization is given importance by the her/his superior (Aselage and Eisenberger, 2003). Superiors in the eyes of the employees are in the position of agents of the organization and superiors transfer all declarations related to the organization. Therefore, it has been identified that as the perceived superior support increases, organizational increases as well (Eisenberger et al., 2002). Procedural justice, which is the third antecedent, expresses the justice in the distribution of resources within the organization (Greenberg, 1990). Distribution of resource or rewards is a reflection of plans and procedures within the organization. Deviating from formal procedures in salary or promotion systems within the organization will affect perceived organizational support negatively (Cropanzano et al., 1997). 
According to the hypothetical model that Aselage and Eisenberger (2003) developed on organizational support theory, three moderators exist that affect perceived organizational support. First of these is "discretionary selection". Discretionary selection stresses that the existence of the mutual relationship between employees and their organization is not sufficient, and this interaction will be meaningful for the employees in case it is based on voluntariness. More clearly, in the process of benefitting mutually, the organization should offer the opportunities it provides to its employees not mandatorily but voluntarily. For instance, it should provide improvements in salary or promotion opportunities by itself, not through unions or strikes (Eisenberger et al., 1997; Aselage and Eisenberger, 2003). The second moderator variable that affects perceived organizational support is the perceived status of the superior within the organization. If the superior has a position within the organization that concretes with organization identity, she/he will be expected to influence perceived organizational support at a much higher level (Eisenberger et al., 2002). Especially in cases, in which the superior's importance is known by her/his superiors and correspondingly she/he plays an effective role in decision processes, this influence is expected to increase even more. Aselage and Eisenberger (2003) mentioned the importance of individuals' collective behaviorist tendencies as a third moderator variable. The fact that collective behaviorist individuals have more loyalty for group membership enables their perception against organization's management to be much more sensitive. For this reason, in organizations, in which collective behaviorism is high, perceived organizational support will be expected to be affected much more positively or negatively (Aselage and Eisenberger, 2003).

On the other hand as we approach perceived organizational support in terms of variables it effects, it is claimed to significantly affect outcomes such as job satisfaction, organizational commitment, performance and intention to quit one's job (Buchanan, 1974; Muse and Stamper, 2007; Rhoades and Eisenberger, 2002; Rhoades et al. 2001). According to Eisenberger et al. (1986), in case that perceived organizational support is not fulfilled at a sufficient level, affective commitment will be expected to increase as well. Rhoades et al. (2001) confirmed that affective commitment has no effect on perceived organizational support, although perceived organizational support effects affective commitment. In their text, Aselage and Eisenberger (2003) defined performance reward expectation variable as a variable that perceived organizational support effects. Perceived organizational support to be high will mean expectations of employees towards being rewarded to increase again.

Analyses of management and organization literature about organizational support concentrate on employee performance. It is obvious that perceived organizational support, which stands for paying attention, approving and respecting employees, fulfills psychological needs, strengthens communication between employees and provides a role status in social life. In addition, opinion of the employee that the organization will reward her/him in a way will be a sufficient result for her/him to increase individual performance (Rhoades and Eisenberger, 2002: 702). However, as will be noticed, these findings focus on the performance of the employee. How the organizational support concept will result in terms of employee behaviors, when performance concept is approached with regards to the organization instead of the individual, is an object of interest. Performance of an employee, who receives support from the organization at a high level, can be expected to increase. However, it is not certain whether this 
employee will produce the same outputs in a period, in which the performance of the organization decreases because of environmental reasons. Studies, in which such effects are measured, found in limited numbers.

Similarly, career satisfaction concept is also an important concept in terms of human resources practices. Number of studies that mention perceived organizational support and career satisfaction in the literature are also quite limited. Our purpose in this study will be to examine the effect of perceived organizational support on career satisfaction in two distinct organization types, in which organizational performance is high or low.

\section{Relationship between Perceived Organizational Support and Career Satisfaction}

Career is a term that became a current issue in 1970s and has had a great variety of definitions. In the ongoing process, career has been defined as a process that can provide also psychological satisfaction to individuals beyond vertical advancement in organizational structure as one-dimensional. Career success is the aggregation of psychological or job related positive results or benefits, which an individual reaches through work experiences (Judge et al., 1995). Yet, career satisfaction refers to a person's subjective reflection and evaluation of his or her professional development across individually relevant dimensions (Heslin, 2005). Within the organization an individual's vertical improvement is depended on the evaluation of people at managerial positions. There a large number of environmental variables in and out of the organization that provide this improvement. Even if the individual makes a vertical progress in the process, this process may not be a sufficient progress for her/him. Therefore, to what extent the employee will be satisfied with her/his career depends mostly on a subjective evaluation. Given the time and energy that people typically invest to attain individually important needs and goals in their career, career satisfaction results partially from the subjective evaluation of whether these goals have been attained (Judge, et al., 1995).

Objective career success can be explained as the way salary and status gained in business life are evaluated by the society. Subjective career success, which is the opposite of this, on the other hand is approached as the success perception of the individual gained in her/his career and future expectations (Thomas et al., 2005). In other words, subjective career success is the self-evaluation of the person towards her/his own achievements. Career satisfaction on the other hand, is appraised as the pleasure felt from the level of achievements to goals determined in the career (Greenhaus et al., 1990). Career success, which is evaluated by another individual and which includes elements such as salary and promotion that are not under the control of the individual, is named as "objective career success" (Heslin, 2005: 115). However, previous research put forward that many individuals assessed as "successful" from the outside are not satisfied from their personal achievements and current situations (Judge et al., 1995). Characteristics of the individual caused by her/his personality shape business and career life, and influence perception types of objective conditions (work environment, career level, income obtained, promotion opportunities and etc.), as well as they affect private life (Ozer and Tozkoparan, 2012). Because of this reason, evaluating the subjective aspect of the career success is also important.

Many researches have been conducted with the aim of determining positive and negative organizational outcomes of career satisfaction that depend on personal emotional tendencies of employees towards career (Igbaria, Greenhaus and Parasuraman, 1991). As a result of the 
researches done, relationship of career satisfaction with variables such as performance, commitment, intention to quit job, support for change and gains obtained has been identified (Greenhaus, Panasuraman and Wormley, 1990; Gaertner, 1989; Seibert and Kraimer, 2001). Employees have more satisfaction and exhibit positive organizational behaviors when the position they are in is compatible with their desires (Sullivan, Garden and Martin, 1998).

In addition to these studies, in a few studies career satisfaction has been handled as a sub-variable of subjective career success, together with job satisfaction (Gattiker and Larwood, 1987; Judge et al. 1995). According to Judge et al. (1995) since subjective career success includes momentary status at current job, it includes also the current job satisfaction. Approaching career satisfaction and job satisfaction together as a sub-variable of subjective career satisfaction on the other hand has been criticized by some researchers. Job satisfaction is defined as the positive or desired psychological state, as a result of the promotion the individual received or work experiences gained (Locke, Quoting from 1976: Brief and Weiss, 2002, p.282-283). In spite of this, career satisfaction can be defined as the satisfaction that includes individuals' salary, promotion and self-development opportunities, and that individuals gain from the inner and outer dimensions of their careers. Therefore, career satisfaction of an employee may not be high although her/his job satisfaction is (Gattiker and Larwood, 1987; Judge et al., 1995). More clearly, employees may be satisfied by work environment and work conditions, however they may have problems about their career processes. Grenhaus et al (1990) mentioned the importance of professional success, general professional goals, income expectations, professional improvement and gaining new skills, with regards to employees obtaining career satisfaction.

POS is a strong predictor for career satisfaction because it facilitates the achievement of individual career goals (Cable and DeRue 2002; Karatepe, 2012). When employees perceive that management of the firm is unsupportive to them, they appear to view their jobs as displeasing and have job dissatisfaction (Susskind et al., 2000). Such perceptions demonstrate that the organization does not have the caring, approval, and respect for employees and further indicate that the organization does not provide adequate aid, whenever needed, to carry out job-related tasks effectively (Rhoades and Eisenberger, 2002). In an organization, where organizational support perception is not enough, career dissatisfaction will emerge since it will get difficult for employees to gain new skills and achieve their career goals (Karatepe, 2012). Therefore, POS was significantly and positively related to CSAT. Therefore, the following hypothesis is proposed:

\section{H1. POS is positively related to employees' CSAT.}

\section{The Effects of Organizational Performance on POS - CSAT Relationship}

Organizations have started to give more importance to performance development topic, in order to survive in a changing competition environment. Performance can be explained as the ability of an organization to achieve its goals by using its resources efficiently and effectively (Daft, 2000). Organizational working conditions, physical conditions, organizational aims and all problems that could occur depending on these are deterministic criteria for organizational performance. The most basic problem about performance is how to measure performance. Too little consensus exists in the studies about organizational performance measurement. The main problem is not how organizational performance should be measured, but what needs to be 
measured and how definitions and techniques will be selected. According to Guest (1997: 267), there are three types of performance measurements generally accepted in the literature: (1) Product and service outcome measurements (such as number of products, number of customers, number of defects occurring as a result of manufacturing, customer complaints), (2) time measurement outputs (such as delay time, absenteeism, loss of work hours), (3) financial outputs (such as profit, sales development, Tobin's q).

The relationship of human resources practices such as career satisfaction with performance has often been discussed in the literature. According to Truss (2001), increasing organizational performance enables increasing employees' loyalty, technical knowledge, skills and abilities, increasing the efficiency of HRM practices and decreasing employee turnover in the short term. On the other hand, in the long term realization of organizational goals is assured. The common ground of these studies, which explain the relationship between HRM practices and organizational performance, is in the direction of HRM practices to effect organizational performance (Huselid, 1995; Delery and Doty, 1996; Ichniowski et al., 1997, Pfeffer, 1998). However, since the second half of 90s, studies, which put forward that HRM practices do not directly affect organizational performance, appeared. This point of view claims that organizational performance is not affected by HRM practices, but by attitudes and behaviors of employees. Additionally, this point of view also accepts the existence of moderator variables that explain the relationship between two variables (MacDuffie, 1995; Huselid, 1995; Boselie et al., 2005; Guest, 2001).

According to this model, organizations that have higher financial conditions have the opportunity to invest more in HRM practices. The organization to increase its market share or profit also increases its will to invest in HR practices. Increased investment in HR practices on the other hand means employees to have more gains. Employees will be able to develop their technical abilities and have the opportunity to create additional income with the abilities they gain. Investments in the periods when performance is high will increase the efficiency of team work, quality circle and other empowerment activities (Wright et al., 2005). Besides, in the periods when organizational performance is high, trust levels, commitments, job and career satisfaction of employees will increase as well (Paauwe and Richardson, 1997). In summary, organizational performance to be high causes work outcomes to increase in a positive direction.

Constitution of the interaction between managers and employees depending on mutual trust and by assuring a quality communication will improve job and career satisfaction of employees. In the process of obtaining this satisfaction, organizational performance is an important moderator variable. In periods, especially when environmental uncertainty is high, limitations of investments towards employees will be observed. Because of this reason, differences will be expected to occur in attitudes and behaviors of employees between periods with high performance and low performance. Therefore, the following hypothesis is proposed:

H2. Perceived organizational support (POS) effects career satisfaction (CSAT) in organizations, in which organizational performance is high, compared to organizations, in which organizational performance is low. 


\section{Methodology}

In order to find answers to our hypothesis we carried out quantitative research and applied questionnaire as our method of data collection. Our questionnaire is designed for the purpose of measuring demographic and other types of variables. Research sample is constituted with 10 insurance companies and 194 employees working in these companies. The main reason for insurance sector to be chosen as the target population of the study is the increase in the number of firms that downsize in the sector, with the intense intervention of the government to insurance sector. In the last 10 years, expectations of the government from insurance sector have increased. Insurance Law to come into force, encouragement of Individual Pension System and European Union adaptation studies are each an indicator of increased expectation and interest of the Turkish Republic regarding insurance sector. Correspondingly, a large number of laws and regulations were carried into effect, and severe sanctions were applied regarding the financial obligations of insurance businesses. The will to base the insurance system on solid grounds brought together regulations that include severe sanctions and financial obligations for insurance businesses (for instance Solvency II criteria). Against these sanctions, problems occurred in financial obligations of the insurance businesses, especially which rank around the middle in competition. Some of the insurance businesses were observed to prefer downsizing strategy depending on performance, both because of deterioration in financial structure, and low profitability despite sectorial premium increase. Within this context, they tried to reduce expense items with strategies such as decreasing the number of personnel working in regional directorates in Anatolia, moving some units in the regions to head Office and decreasing the commission paid to insurance experts or agents.

From this point forth, income statements of all insurance firms operating in Turkey for the last four years were analyzed and lists were formed according to their technical profitability. Technical profit means of the last four years were taken from the lists obtained and five insurance businesses with the highest and lowest performance were decided to be included in the sample.

Table 1. Technical Profits of Companies (US Dollar)

\begin{tabular}{|c|c|c|c|c|c|c|}
\hline & & 2014 & 2013 & 2012 & 2014* & $\begin{array}{l}\text { Average Technical } \\
\text { Profit for Four Years }\end{array}$ \\
\hline \multirow{5}{*}{ 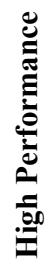 } & Allianz Insurance A.S. & 46.404 .387 & 65.647 .967 & 37.683 .742 & 27.998 .431 & 44.433 .632 \\
\hline & Yapi Kredi Insurance A.S. & 36.034 .165 & 30.973 .402 & 38.412 .753 & 27.258 .823 & 33.169 .786 \\
\hline & Ak Insurance A.S. & 13.996 .358 & 45.469 .813 & 24.550 .786 & 16.500 .134 & 25.129 .273 \\
\hline & Ziraat Insurance A.S. & 19.683 .498 & 29.942 .710 & 25.988 .927 & 24.128 .424 & 24.935 .890 \\
\hline & Sompo Japan Insurance A.S. & 15.584 .282 & 17.552 .740 & 13.752 .932 & 14.400 .432 & 15.322 .597 \\
\hline \multirow{5}{*}{ 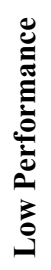 } & Groupama Insurance A.S. & -5.452 .800 & -508.153 & -6.755 .254 & -3.974 .188 & -4.172 .599 \\
\hline & Generali Insurance A.S. & -8.772 .221 & -9.548 .093 & -1.630 .014 & -4.875 .000 & -6.206 .332 \\
\hline & Hur Insurance A.S. & -8.794 .627 & -20.371 .092 & -2.047 .441 & -2.040 .094 & -8.313 .313 \\
\hline & Liberty Insurance A.S. & -7.515 .952 & -4.477 .260 & -26.581 .971 & -18.024 .089 & -14.149 .818 \\
\hline & Aviva Insurance A.S. & -33.418 .484 & -4.924 .321 & -25.895 .270 & -19.404 .413 & -20.910 .622 \\
\hline
\end{tabular}


The questionnaire is applied to companies both in İstanbul head offices and district offices in Ankara. Employees from each insurance company help us to make sure that the questionnaire has been filled out by respondents who are mainly responsible with insurance related tasks. The respondents were informed that we would keep the answers anonymous. Accordingly, we did not record their names on the questionnaire forms and we guaranteed that the data would be kept confidential and not be reached by the respondents' supervisors. The valid questionnaires were identified after the questionnaire has been administered and collected. All analyses have been conducted though those who agreed to fill out a questionnaire. In the research, SPSS statistical program has been used for finding the frequency distributions. Afterwards, through our research hypothesis, the correlation analysis and multiple regression analysis are applied. The demographic information of the respondents can be seen below (Table 2).

Table 2. Demographic Characteristics of Sample

\begin{tabular}{|c|c|c|}
\hline & $\begin{array}{c}\text { Low Performance } \\
\text { Companies } \\
\%\end{array}$ & $\begin{array}{c}\text { High Performance } \\
\text { Companies } \\
\%\end{array}$ \\
\hline \multicolumn{3}{|l|}{ Age } \\
\hline $21-30$ & 21,3 & 24,7 \\
\hline $31-40$ & 49,2 & 43,1 \\
\hline $41-50$ & 20,6 & 19,0 \\
\hline $51+$ & 8,9 & 13,2 \\
\hline \multicolumn{3}{|l|}{ Sex } \\
\hline Female & 58,9 & 57,1 \\
\hline Male & 41,1 & 42,6 \\
\hline \multicolumn{3}{|l|}{ Education } \\
\hline Primary School & 0,0 & 0,0 \\
\hline High School & 7,0 & 7,1 \\
\hline Associate/Bachelor & 83,7 & 79,6 \\
\hline Master/PhD & 9,3 & 13,3 \\
\hline Average Tenure (Year) & 7,1 & 7,5 \\
\hline Average Employee Age & 28,6 & 31,0 \\
\hline Sampling Size (person) & 87 & 107 \\
\hline Sampling Size (company) & 5 & 5 \\
\hline
\end{tabular}

\subsection{Scales}

The questionnaire form of the research consists of two sections. In the first section, the form consists of questions to specify the demographic factors of the employees. The first section, the 
questionnaire the person, gender, age, education level, job title, work, unit, how long this business has been running and how long the supervisor is working with the determination has been attempted. In the second section of questionnaire, perceived organizational support scale of Eisenberger et al. (1986) consists of 36 items and career satisfaction scale of Greenhaus et al. (1990) consists of 5 items were used. SPSS 12.0 statistical data were analyzed by analysis software package.

\subsection{Findings}

Reliability analysis of perceived organizational support and career satisfaction levels are calculated in the first part of analysis. According to the results of reliability analysis $\alpha>0.60$ based on the value of the scales were found to have adequate reliability (see Table 4 and 5). Subsequently, the difference between the mean values of perceived organizational support and career satisfaction levels of organizations were tested for low and high performance organizations. With this purpose, t-test analysis was applied. While the results obtained demonstrate that career satisfaction level puts forward statistically different results in two organization groups' performance; a significant difference was not identified perceived organizational support level (Table 3).

In order to test the hypothesis, the correlation analysis for the research variables of low and high performance organizations are examined in the second stage. A statistically significant relationship in a positive direction was identified between perceived organizational support and career satisfaction in both organization groups. This relationship to be much stronger in high performance organizations attracts attention (see Table 4 and 5).

Table 3. The Mean, Standard deviation and t values of organizations

\begin{tabular}{|l|c|c|c|c|}
\hline & \multicolumn{2}{|c|}{ Perceived Organizational Support } & \multicolumn{2}{c|}{ Career Satisfaction } \\
\hline & $\begin{array}{c}\text { Low Performance } \\
\text { Companies }\end{array}$ & $\begin{array}{c}\text { High Performance } \\
\text { Companies }\end{array}$ & $\begin{array}{c}\text { Low Performance } \\
\text { Companies }\end{array}$ & $\begin{array}{c}\text { High Performance } \\
\text { Companies }\end{array}$ \\
\hline Sample & 87 & 107 & 87 & 107 \\
\hline Mean & 3.4 & 3.6 & 3.1 & 3.8 \\
\hline St. Dev. & 1.14 & 1.03 & 1.01 & 0.91 \\
\hline T values & \multicolumn{2}{|c|}{5.77} & & 3.96 \\
\hline Sig. (P) & \multicolumn{2}{|c|}{0.246} & & $0.091 *$ \\
\hline
\end{tabular}

${ }^{*} \mathrm{p}<0.10$ 
Table 4. Correlation Analysis for Low Performance Organization

\begin{tabular}{|l|c|c|c|c|c|c|c|c|c|}
\hline & Mean & SD & $\mathbf{1}$ & $\mathbf{2}$ & $\mathbf{3}$ & $\mathbf{4}$ & $\mathbf{5}$ & $\mathbf{6}$ & $\mathbf{7}$ \\
\hline 1. Gender & - & - & & & & & & & \\
\hline 2. Position & - & - & .32 & & & & & & \\
\hline 3. Age & 28,6 & 6.13 & .21 & $.13^{* *}$ & & & & & \\
\hline 4. Tenure & 7,1 & 5.10 & .17 & $.20^{* *}$ & $.24^{* *}$ & & & & \\
\hline 5. Education & - & - & .24 & $.17^{* *}$ & .45 & .28 & & & \\
\hline $\begin{array}{l}\text { 6. Perceived } \\
\text { Organizational Support }\end{array}$ & 3.4 & 1.14 & .16 & .26 & $.27^{* *}$ & $.19^{* *}$ & $.16^{*}$ & $\mathbf{( . 7 3 )}$ & \\
\hline 7. Career Satisfaction & 3.1 & 1.01 & .08 & $.31^{*}$ & $.19^{*}$ & $.09^{*}$ & $.14^{*}$ & $.17^{* *}$ & $\mathbf{( . 6 2 )}$ \\
\hline
\end{tabular}

${ }^{*} \mathrm{p}<0.05,{ }^{* *} \mathrm{p}<0.01$

Table 5. Correlation Analysis for High Performance Organization

\begin{tabular}{|l|c|c|c|c|c|c|c|c|c|}
\hline & Mean & SD & $\mathbf{1}$ & $\mathbf{2}$ & $\mathbf{3}$ & $\mathbf{4}$ & $\mathbf{5}$ & $\mathbf{6}$ & $\mathbf{7}$ \\
\hline 1. Gender & - & - & & & & & & & \\
\hline 2. Position & - & - & .51 & & & & & & \\
\hline 3. Age & 31.0 & 6.89 & .45 & $.21^{*}$ & & & & & \\
\hline 4. Tenure & 7,5 & 5.23 & .09 & $.31^{* *}$ & $.29^{* *}$ & & & & \\
\hline 5. Education & - & - & .22 & $.11^{* *}$ & .05 & .11 & & & \\
\hline $\begin{array}{l}\text { 6. Perceived } \\
\text { Organizational Support }\end{array}$ & 3.6 & 1.03 & .34 & $.20^{* *}$ & $.17^{*}$ & $.31^{* *}$ & $.23^{*}$ & $\mathbf{( . 7 0 )}$ & \\
\hline 7. Career Satisfaction & 3.8 & 0.91 & .38 & $-.23^{* *}$ & $.25^{*}$ & $.11^{* *}$ & .34 & $.31^{* *}$ & $\mathbf{( . 6 4 )}$ \\
\hline
\end{tabular}

$* \mathrm{p}<0.05, * * \mathrm{p}<0.01$

In the third stage, regression analysis was applied with the aim to test at what level gender, position, age, tenure, education and perceived organizational support values explain career satisfaction. Findings obtained from regression analysis put forward that in low performance organizations position, age, tenure, education and perceived organizational support values explain career satisfaction at a significant level $\left(\mathrm{R}^{2}=.17, \mathrm{~F}=41.11, \mathrm{p}<.01\right)$. On the other hand, all variables were determined to explain career satisfaction at a significant level in high performance organizations $\left(\mathrm{R}^{2}=.25, \mathrm{~F}=45.17, \mathrm{p}<.01\right)$. In addition to this, while Perceived Organizational Support explains $22 \%$ of the variance in low performance organizations, it explains $30 \%$ of the variance in high performance organizations (Table 6). After the correlation and regression analysis, it can be said that Perceived Organizational Support in high performance organizations affects career satisfaction in higher level and positively compared to low performance organizations. Thus, we can claim that our hypothesis is confirmed as a result of the study. 
Table 6. Multiple Regression Analysis for Career Satisfaction

\begin{tabular}{|c|c|c|c|c|c|c|c|c|}
\hline & \multicolumn{4}{|c|}{ Low Performance Organization } & \multicolumn{4}{|c|}{ High Performance Organization } \\
\hline & $\mathbf{N}$ & $\boldsymbol{\beta}$ & $\mathbf{R 2}$ & $\mathbf{F}$ & $\mathbf{N}$ & $\beta$ & R2 & $\mathbf{F}$ \\
\hline 1. Gender & \multirow{6}{*}{87} & 0.095 & \multirow{6}{*}{0.17} & \multirow{6}{*}{$41.11 * *$} & \multirow{6}{*}{107} & $0.102 *$ & \multirow{6}{*}{0.25} & \multirow{6}{*}{$45.17 * *$} \\
\hline 2. Position & & $0.085^{* *}$ & & & & $0.174 * *$ & & \\
\hline 3. Age & & $0.117^{* *}$ & & & & $0.185^{* *}$ & & \\
\hline 4. Tenure & & $0.081^{*}$ & & & & $0.131^{*}$ & & \\
\hline 5. Education & & $0.011^{*}$ & & & & $0.068^{*}$ & & \\
\hline $\begin{array}{l}\text { 6. Perceived Organizational } \\
\text { Support }\end{array}$ & & $0.221^{* *}$ & & & & $0.298 * *$ & & \\
\hline
\end{tabular}

${ }^{*} \mathrm{p}<0.05,{ }^{* *} \mathrm{p}<0.01$

\section{Conclusion}

The results clearly suggest that the overall hypothesized model is applicable and two hypotheses are supported. The result regarding the effect of POS on CSAT lends support to other studies in the relevant literature (Karatepe, 2012; Armstrong-Stassen and Ursel, 2009; Erdogan et al., 2004). The availability of sufficient support provided by the organization suggests that the organization values employees' contributions and cares about their well-being. Employees with adequate organizational support are satisfied with their career in terms of pay, advancement, achievement of career goals, and development of new skills in the current jobs (Karatepe, 2012: 746). In order for not to disappoint the expectations of the employees for the future, career development of employees should be planned and supported by managers. Expecting efforts for the sake of the organization will not be much possible from employee, whose career satisfaction decreases.

Our purpose in the study was not only to examine the relationship between the organizational support level that employees perceive and their career satisfaction; but it was also to test how the interaction between these variables change in the process of the organization to adapt to environmental pressures. Within this framework, we examined whether there is a significant difference occurs in the interaction of POS-CSAT in cases, in which organizational performance is high or low. Results show that perceived organizational support effects career satisfaction more in high performance organizations, compared to low performance organizations. Organizations that have especially high financial conditions and market share have the opportunity to invest more in HR practices. This situation on the other hand affects many HR outputs, particularly career satisfaction. Accordingly, periods in which organizational profitability are high are periods that employees can clarify their career processes. As a result, it can be thought that concerns of employees for the future decrease and their desire to work on behalf of the organization increase in these periods.

The main limitation of our study is the fact that it has been applied in the insurance industry. Although insurance industry is one of the most important sectors among service sectors, our study can be tested on different goods and service sectors with alternative models. 


\section{References}

Armstrong-Stassen, M., \& Ursel, N. D. (2009). Perceived organizational support, career satisfaction, and the retention of older workers. Journal of Occupational and Organizational Psychology, 82, 210-220. http://dx.doi.org/10.1348/096317908X288838

Aselage, J., \& Eisenberger, R. (2003). Perceived organizational support and psychological contracts: A theoretical integration. Journal of Organizational Behavior, 24, 491-509. http://dx.doi.org/10.1002/job.211

Blau P. M. (1964). Exchange and Power in Social Life, New York: Wiley.

Boselie, P., Dietz, G., \& Boon, C. (2005). Commonalities and contradictions in research on Human Resource Management and Performance. Human Resource Management Journal, 15(3), 67-94. http://dx.doi.org/10.1111/j.1748-8583.2005.tb00154.x

Brief, A. P., \& Weiss, H. M. (2002). Organizational behavior: Affect in the workplace. Annual Review of Psychology, 279-307. http://dx.doi.org/10.1146/annurev.psych.53.100901.135156

Buchanan, B., II. (1974). Building organizational commitment: The socialization of managers in work organizations. Administrative Science Quarterly, 19, 533-546. http://dx.doi.org/10.2307/2391809

Cable, D. M., \& DeRue, D. S. (2002). The convergent and discriminant validity of subjective fit perceptions. Journal of Applied Psychology, 87, 875-884. http://dx.doi.org/10.1037/0021-9010.87.5.875

Cropanzano, R., Howes, J. C., Grandey, A. A., \& Toth, P. (1997). The relationship of organizational politics and support to work behaviors, attitudes, and stress. Journal of Organizational Behavior, 22, 159-180. http://dx.doi.org/10.1002/(SICI)1099-1379(199703)18:2<159::AID-JOB795>3.0.CO;2-D

Cropanzano, R., \& Mitchell, M.S. (2005). Social exchange theory: An interdisciplinary review, Journal of Management, 31, 874-900. http://dx.doi.org/10.1177/0149206305279602

Daft, R.L. (2000). Organization Theory and Design, 7 th Edition, Mason: South-Western College Publishing.

Delery. J.E., \& Doty. H.D. (1996) Modes of Theorizing in Strategic Human Resource Management: Tests of Universalistic, Contingency, and Configurational Performance predictions. Academy of Management Journal, 39(4), 802-35. http://dx.doi.org/10.2307/256713

Eisenberger, R., Huntington, R., Hutchison, S., \& Sowa, D. (1986). Perceived Organizational

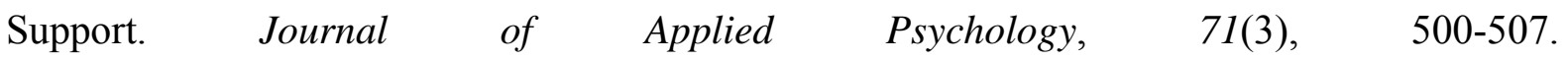
http://dx.doi.org/10.1037/0021-9010.71.3.500 
Eisenberger, R., Rhoades, L., \& Cameron, J. (1999). Does pay for performance increase or decrease perceived self-determination and intrinsic motivation?, Journal of Personality and Social Psychology, 77, 1026-1040. http://dx.doi.org/10.1037/0022-3514.77.5.1026

Eisenberger, R., Stinglhamber, F., Vandenberghe, C., Sucharski, I., \& Rhoades, L. (2002). Perceived supervisor support: Contributions to perceived organizational support and employee retention, Journal of Applied Psychology, 87, 565-573. http://dx.doi.org/10.1037/0021-9010.87.3.565

Gaertner, K. N. (1989). Winning and Losing: Understanding Managers' Reactions to Strategic Change. Human Relations, 42, 527-546. http://dx.doi.org/10.1177/001872678904200604

Gattiker, U., \& Larwood, L. (1987). Women's Career Development (A Comparison of the Career Paths Used By Successful Women and Men), SAGE Publications Newbury Park, CA

Gouldner, A.W. (1960). The norm of reciprocity: A preliminary statement. American Sociological Review, 25, 161-78. http://dx.doi.org/10.2307/2092623

Greenberg, J. (1990). Organizational justice: Yesterday, today and tomorrow. Journal of Management, 16, 399-432. http://dx.doi.org/10.1177/014920639001600208

Guest, D. (1997). Human Resource Management and Performance: A Review and Research Agenda, International Journal of Human Resource Management, 8(3), 263-275. http://dx.doi.org/10.1080/095851997341630

Guest, D.E. (2001). Human resource management: when research confronts theory. International Journal of Human Resource Management, 12(7), 1092-1106. http://dx.doi.org/10.1080/09585190110067837

Guest, D.E., Mitchie, J., Conwey, N., \& Sheedan, M. (2003). Human Resource Management and Corporate Performance in the UK, British Journal of Industrial Relations, 41(2), 291-314. http://dx.doi.org/10.1111/1467-8543.00273

Greenhaus, J. H., Parasuraman, S., \& Wormley, W. M. (1990). Effects of race on organizational experiences, job performance evaluations, and career outcomes. Academy of Management Journal, 33, 64-86. http://dx.doi.org/10.2307/256352

Heslin, P. (2005). Conceptualizing and evaluating career success. Journal of Organizational Behaviour, 2, 113-136. http://dx.doi.org/10.1002/job.270

Huselid, M. A. (1995). The Impact of Human Resource Management Practices on Turnover, Productivity, and Corporate Financial Performance. Academy of Management Journal, 38, 635-672. http://dx.doi.org/10.2307/256741

Ichniowski, C., Shaw, K., \& Prennushi, G. (1997). The effects of human resource management practices on productivity. American Economic Review, 87, 291-313. 
Igbaria, M., Greenhaus, J. H., \& Parasuraman, S. (1991). Career orientations of MIS employees: an empirical analysis. MIS quarterly, 6, 151-169. http://dx.doi.org/10.2307/249376

Judge, T. A., Cable, D. M., Boudreau, J. W., \& Bretz, R. D. (1995). An empirical investigation of the predictors of executive career success. Personnel Psychology, 48, 485-519. http://dx.doi.org/10.1111/j.1744-6570.1995.tb01767.x

Karatepe, O.M. (2012). Perceived organizational support, career satisfaction, and performance outcomes: a study of hotel employees in Cameroon. International Journal of $\begin{array}{llll}\text { Contemporary Hospitality } \quad \text { Management, 24(5), } & \text { 735-52. }\end{array}$ http://dx.doi.org/10.1108/09596111211237273

Locke, E. A. (1976). The nature and causes of job satisfaction. In M. D. Dunnette (Ed.), Handbook of Industrial and Organizational Psychology, Chicago: Rand McNally, 1297-1349.

MacDuffie, J. P. (1995), Human Resource Bundles and Manufacturing Performance: Organizational Logic and Flexible Production Systems in the World Auto Industry, Industrial and Labor Relations Review, 48(2), 197-221. http://dx.doi.org/10.2307/2524483

Muse, L.A., \& Stamper, C.L. (2007) Perceived organizational support and its consequences: Evidence for a mediated association with work performance. Journal of Managerial Issues, 19(4), 517-535.

Ozer, P.S., \& Tozkoparan, G. (2012). An Empirical Study of the Relationship among Core Self Evaluations with Job and Life Satisfaction, Journal of Yasar University, 30(8), 4933-4947.

Paauwe, J., \& Richardson, R. (1997). Introduction special issue on HRM and Performance. International Journal of Human Resource Management, 8(3), 257-262. http://dx.doi.org/10.1080/095851997341621

Pfeffer, J. (1998). Seven practices of successful organizations. California Management Review, 40(2), 96-124. http://dx.doi.org/10.2307/41165935

Rhoades, L., Eisenberger, R., \& Armeli, S. (2001). Affective commitment to the organization: The contribution of perceived organizational support. Journal of Applied Psychology, 86, 825-836. http://dx.doi.org/10.1037/0021-9010.86.5.825

Rhoades, L., \& Eisenberger, R. (2002). Perceived organizational support: A review of the $\begin{array}{lllll}\text { literature. Journal of Applied Psychology, 87, } & \text { 698-714. }\end{array}$ http://dx.doi.org/10.1037/0021-9010.87.4.698

Saks, A.M. (2006). Antecedents and consequences of employee engagement, Journal of Managerial Psychology, 21:6, 600-619. http://dx.doi.org/10.1108/02683940610690169

Seibert, S. E., \& Kraimer, M. L. (2001). The five-factor model of personality and career success. Journal of Vocational Behavior, 58, 1-21. http://dx.doi.org/10.1006/jvbe.2000.1757 


\section{Macrothink}

Journal of Management Research

ISSN 1941-899X 2015, Vol. 7, No. 3

Sullivan, S. E., Garden, W. A., \& Martin, D. F. (1998). Careers in the Next Millennium: Directions for Future Research. Human Resource Management Review, 8(2), 165-185. http://dx.doi.org/10.1016/S1053-4822(98)80003-X

Susskind, A. M., Carl P. B., K. M. K., \& Robert A. B. (2000). Customer service employees' behavioral intentions and attitudes: An examination of construct validity and a path model. International Journal of Hospitality Management 19(1), 53-77. http://dx.doi.org/10.1016/S0278-4319(99)00030-4

Thomas W. H., Eby, L.T., Sorensen, K.L., \& Feldman, D.C. (2005). Predictors of Objective and Subjective Career Success: A Meta-Analysis. Personnel Psychology, 58, 367-408. http://dx.doi.org/10.1111/j.1744-6570.2005.00515.x

Truss, C. (2001). Complexities and Controversies in Linking HRM with Organizational Outcomes, Journal of Management Studies, 38(8), 1122-1149. http://dx.doi.org/10.1111/1467-6486.00275

Wayne, S. J., Shore, L. M., \& Liden., R. C. (1997). Perceived organizational support and leader-member exchange: A social exchange perspective. Academy of Management Journal, 40, 82-111. http://dx.doi.org/10.2307/257021

Wright, P. M., Gardner, T., Moyniham, L. M., \& Allen, M. (2005). The HR performance relationship: Examining causal direction. Personnel Psychology, 58(2), 409-446. http://dx.doi.org/10.1111/j.1744-6570.2005.00487.x

\section{Copyright Disclaimer}

Copyright for this article is retained by the author(s), with first publication rights granted to the journal.

This is an open-access article distributed under the terms and conditions of the Creative Commons Attribution license (http://creativecommons.org/licenses/by/3.0/). 